\title{
Elevated ozone negatively affects photosynthesis of current-year leaves but not previous-year leaves in evergreen Cyclobalanopsis glauca seedlings
}

\author{
Weiwei Zhang $^{\mathrm{a}, \mathrm{b}}$, Zhaozhong Feng ${ }^{\mathrm{b}, *}$, Xiaoke Wang ${ }^{\mathrm{b}, *}$, Junfeng Niu ${ }^{\mathrm{b}}$ \\ ${ }^{a}$ Key Laboratory of Black Soil Ecology, Northeast Institute of Geography and Agroecology, Chinese Academy of Sciences, Harbin 150081, China \\ ${ }^{\mathrm{b}}$ State Key Laboratory of Urban and Regional Ecology, Research Center for Eco-Environmental Sciences, Chinese Academy of Sciences, P. O. 2871, \\ Shuangqing Road 18, Haidian District, Beijing 100085, China
}

\section{A R T I C L E I N F O}

\section{Article history:}

Received 13 January 2013

Received in revised form

24 April 2013

Accepted 26 April 2013

\section{Keywords:}

Chlorophyll $a$ fluorescence

Evergreen tree

Leaf position

Gas exchange

Ozone

\begin{abstract}
A B S T R A C T
To assess the effects of leaf age/layer on the response of photosynthesis to chronic ozone $\left(\mathrm{O}_{3}\right)$, Cyclobalanopsis glauca seedlings, a dominant evergreen broadleaf tree species in sub-tropical regions, were exposed to either ambient air (AA) or elevated $\mathrm{O}_{3}\left(\mathrm{AA}+60 \mathrm{ppb} \mathrm{O}_{3}, \mathrm{E}-\mathrm{O}_{3}\right)$ for two growing seasons in open-top chambers. Chlorophyll content, gas exchange and chlorophyll $a$ fluorescence were investigated three times throughout the 2nd year of $\mathrm{O}_{3}$ exposure. Results indicated that $\mathrm{E}^{-} \mathrm{O}_{3}$ decreased photosynthetic parameters, particularly light-saturated photosynthesis rate, stomatal conductance and effective quantum yield of PSII photochemistry of current-year leaves but not previous-year leaves. Stomatal conductance of plants grown under ambient conditions partially contributed to the different response to $\mathrm{E}-\mathrm{O}_{3}$ between leaf layers. Light radiation or other physiological and biochemical processes closely related to photosynthesis might play important roles. All suggested that leaf ages or layers should be considered when assessing $\mathrm{O}_{3}$ risk on evergreen woody species.
\end{abstract}

(c) 2013 Elsevier Ltd. All rights reserved.

\section{Introduction}

Ground-level ozone $\left(\mathrm{O}_{3}\right)$ has received global concern due to its strong toxicity on agricultural crops, semi-natural vegetation and forest trees, and as a result of rising global background and regional peak $\mathrm{O}_{3}$ concentrations (e.g. Asia) (Feng and Kobayashi, 2009; The Royal Society, 2008). Numerous experimental studies have demonstrated the detrimental effects of $\mathrm{O}_{3}$ on tree species growth and physiological function, e.g. photosynthesis (Bagard et al., 2008; Feng et al., 2011; Schaub et al., 2005; Wittig et al., 2009; Zhang et al., 2010). The reduction in photosynthesis rate by $\mathrm{O}_{3}$ could be attributed to stomatal closure, decreased chlorophyll content and electron transport rate, impaired carboxylation capacity and Rubisco content (Paoletti et al., 2009; Reich, 1983). Although the reduction in Rubisco activity was assumed to be the primary cause in photosynthetic decline under $\mathrm{O}_{3}$ stress, stoma appeared to an important factor controlling $\mathrm{O}_{3}$ entering the leaf interior (Novak et al., 2005). Therefore, the response of stomatal conductance $\left(g_{s}\right)$

\footnotetext{
* Corresponding authors.

E-mail addresses: zhzhfeng201@hotmail.com, fzz@rcees.ac.cn (Z. Feng), wangxk@rcees.ac.cn (X. Wang).
}

to $\mathrm{O}_{3}$ at different leaf ages could influence the stomatal $\mathrm{O}_{3}$ uptake and further leaf tissue injury.

Previous studies have demonstrated that the effects of $\mathrm{O}_{3}$ on gas exchange are influenced by leaf age (Bohler et al., 2010; Coleman et al., 1995; Pääkkönen et al., 1996) and leaf position within canopy (Samuelson and Edwards, 1993; Schaub et al., 2005) when growing under the same conditions. For hybrid poplar and Aspen, elevated $\mathrm{O}_{3}$ concentrations altered the patterns of change in leaf area, photosynthetic rate and carbon gain with leaf position from root to apex and the older leaves were more sensitive to $\mathrm{O}_{3}$ than younger leaves (Bagard et al., 2008; Greitner et al., 1994). At the canopy level, ambient $\mathrm{O}_{3}$ concentrations caused reductions in both light-saturated photosynthesis rate $\left(A_{\mathrm{sat}}\right)$ and $g_{\mathrm{s}}$ of the lower canopy that were about $30 \%$ more than those of the upper canopy in black poplar (Populus nigra L.) species (Novak et al., 2005). Young poplar trees also showed that reduced photosynthetic parameters related to chlorophyll content, maximum rate of photosynthetic electron transport and net photosynthetic assimilation appeared only on fully expanded leaves, but not on young and undeveloped leaves, which was partly attributed to differences in leaf anatomy between expanding and fully expanded leaves (Bagard et al., 2008). Similarly, for an evergreen broad-leaved species, Castanaopsis sieboldii, elevated $\mathrm{O}_{3}$ significantly reduced the net photosynthetic rate 
of previous-year leaves but not that of expanding current-year leaves (Watanabe et al., 2008).

However, given the differences of leaf growth habit between deciduous and evergreen species, and lower $g_{s}$ in old (previousyears) leaves compared to young (current-year) leaves for evergreen species, it can be inferred that the response to $\mathrm{O}_{3}$ among leaf ages of evergreen species might be different from that of deciduous species. Therefore, it is necessary to further investigate the effects of $\mathrm{O}_{3}$ on the photosynthesis characteristics of evergreen species at different leaf ages/layers, which is critical for ozone risk assessment since most leaves of evergreen species are exposed to $\mathrm{O}_{3}$ for many years.

In this study, we selected Cyclobalanopsis glauca, an evergreen broadleaf tree species widely distributed in sub-tropical forests, to investigate the negative effects of elevated $\mathrm{O}_{3}$ on photosynthetic parameters, including chlorophyll content, gas exchange and photosynthetic electron transport at different leaf ages/positions. The objectives of this study are to determine whether impacts of $\mathrm{O}_{3}$ on photosynthesis depend on leaf age or leaf layer, and to explore possible mechanisms.

\section{Materials and methods}

\subsection{Experimental site}

The experimental site was located at the Tiantong National Field Observation and Research Station for Subtropical Forest Ecosystems $\left(29^{\circ} 48^{\prime} \mathrm{N}, 121^{\circ} 47^{\prime} \mathrm{E}\right)$, Ningbo, Zhejiang Province, China. It is typical of the humid subtropical monsoon climate with cold dry winters and warm wet summers. The annual mean temperature is $16.2^{\circ} \mathrm{C}$ and the warmest month is July with a mean temperature of $28.1^{\circ} \mathrm{C}$. Average annual precipitation is $1375 \mathrm{~mm}$, concentrated between June and August.

\subsection{Plant materials}

One-year-old seedlings of Cyclobalanopsis glauca L. were individually planted into $6 \mathrm{~L}$ circular plastic pots in a temperature controlled and double glazed greenhouse $\left(25 \pm 2{ }^{\circ} \mathrm{C}\right.$, air relative humility 70-90\%) from November 2008 until the middle of April 2009. Pots were filled with native yellowish brown lateritic soil (soil organic C $0.98 \%$, total $\mathrm{N} 1.36 \mathrm{~g} \mathrm{~kg}^{-1}$, total P $0.27 \mathrm{~g} \mathrm{~kg}^{-1}$, total $\mathrm{K} 1.41 \%$ ) in mixture with litter collected under firry forest in the ratio of $1: 1(\mathrm{v} / \mathrm{v})$. Seedlings with similar height and basal diameter were selected for this study and pre-adapted to open-top chambers (OTCs) conditions for two weeks before $\mathrm{O}_{3}$ fumigation. During cultivation and $\mathrm{O}_{3}$ exposure, plants were well watered with tap water to avoid drought stress.

\subsection{Ozone exposure}

There were two treatments: ambient air (AA) and ambient air with the addition of $60 \mathrm{ppb} \mathrm{O}_{3}\left(\mathrm{E}-\mathrm{O}_{3}\right)$, with two replicate chambers for each treatment. Four OTCs (octagonal base, $7 \mathrm{~m}^{2}$ of growth space and $2.6 \mathrm{~m}$ in height) were randomly used as $\mathrm{AA}$ and $\mathrm{E}-\mathrm{O}_{3}$ in the field. For $\mathrm{E}-\mathrm{O}_{3}, \mathrm{O}_{3}$ was generated from pure oxygen by an electrical discharge $\mathrm{O}_{3}$ generator (HY003, Chuangcheng Co. Jinan, China) and then mixed with ambient air to achieve the target $\mathrm{O}_{3}$ concentration. The average air velocity in the chambers corresponded to approximately two complete air change per minute. The concentration of $\mathrm{O}_{3}$ within the OTCs was monitored at approximately $10 \mathrm{~cm}$ above the plant canopy using a UV absorption $\mathrm{O}_{3}$ analyzer (Model 49i-Thermo, USA).

For each treatment, seedlings were transposed into two fumigation chambers with 8 plants per chamber. The position of the plants was changed every $5-7$ days within each OTC to eliminate positional effects. Every 10-15 days, the chambers were emptied and randomly reassigned to any $\mathrm{O}_{3}$ treatment, and the seedlings were replaced back according to their specified treatment levels. Plants were fumigated for two growing seasons from 25 May to 10 September 2009 and 2 May to 13 October 2010. There was a daily maximum $\mathrm{O}_{3}$ exposure of $8 \mathrm{~h}$ (from 08:00 to 16:00), because $\mathrm{O}_{3}$ exposure was stopped when there was rain, fog, mist or dew. There were a total of 70 and 79 effective fumigation days during the 2009 and 2010 growing seasons, respectively. During the $\mathrm{O}_{3}$ fumigation of the 2010 growing season, mean air temperature and relative air humidity within and outside the OTCs were 25.2 and $24.9{ }^{\circ} \mathrm{C}, 81.8$ and $88.2 \%$, respectively, and maximum air temperatures and relative air humidity within and outside the OTCs were 32.7 and $31.8{ }^{\circ} \mathrm{C}, 99.0$ and $93.6 \%$, respectively.

\subsection{Measurements}

To investigate the leaf response to $\mathrm{E}_{-} \mathrm{O}_{3}$ at different canopy layers during the growing season, we used a non-destructive approach to conduct measurements on gas exchange, leaf chlorophyll $a$ fluorescence and total chlorophyll contents. Generally, C. glauca produces leaves in spring (April) and summer (July) during the growing season. We recorded the leaf number of the whole plant in monthly censuses, and marked current-year leaves on the main stem for six seedlings from each $\mathrm{O}_{3}$ treatment. The leaves that flushed in spring were fully expanded before the $\mathrm{O}_{3}$ fumigation started, and the number of these leaves averaged 47 and 49 in AA and E$\mathrm{O}_{3}$, respectively. The leaves that flushed in summer developed to be fully expanded during the experiment. Leaf number gradually increased but the position of the leaf in the main shoot changed from upper to lower within the plant canopy during the course of the $\mathrm{O}_{3}$ fumigation. We conducted three measurements from July to September. Here, all measurements were performed between the sixth layers of leaves from the base at main shoot to apex since the lowest layer $(1-5)$ at the base showed very low values of photosynthesis rate. The fully expanded leaf layer at the top of canopy was Layer 17 at the first measurement (18th July) and Layer 21 at the second (17th August) and third (14th September) measurements. At the 3rd measurement, the number of leaves flushed in summer (including fully expanded) was 201 and 190 in $\mathrm{AA}$ and $\mathrm{E}-\mathrm{O}_{3}$, respectively. All selected leaves were defined into three leaf ages, with the lowest and oldest leaves (from Layer 6 to Layer 11) as the mature leaves $(\mathrm{ML})$ formed in the previous year, the leaves in the middle of the canopy (from Layer13 to Layer 17) as young leaves formed in spring (YL), and the three uppermost leaves (from Layer19 to Layer 21) were classified as newly formed leaves in summer (NFL).

\subsubsection{Gas exchange and chlorophyll a fluorescence measurement}

Three plants per chamber were randomly selected and two summer-flushed new leaves, three spring-flushed leaves and three previous-year leaves of each plant were marked for measurements. Gas exchange was determined with a portable photosynthesis system fitted with a 6400-40 leaf chamber fluorometer (LCF) (LI-6400, LICOR Inc. Lincoln, NE, USA). The system controlled saturating PPFD (photosynthetic photon flux density) at $1200 \mu \mathrm{mol} \mathrm{m} \mathrm{m}^{-2} \mathrm{~s}^{-1}$. The block temperature was set to the ambient average of $32{ }^{\circ} \mathrm{C}, \mathrm{CO}_{2}$ at $380 \mu \mathrm{mol} \mathrm{mol}^{-1}$, and relative humidity (RH) at 50-65\%. All measurements were conducted during 09:00-11:00. During gas exchange measurements, chlorophyll $a$ fluorescence parameters were also recorded. All gas exchange and fluorescence measurements were recorded when the stability or steady state indicated by total coefficient of variation was $\leq 3 \%$. For chlorophyll fluorescence, steady state fluorescence yield (Fs) was recorded at saturating PPFD of $1200 \mu \mathrm{mol} \mathrm{m}^{-2} \mathrm{~s}^{-1}$. The intensity of the saturation pulses was $6000 \mu \mathrm{mol} \mathrm{m}^{-2} \mathrm{~s}^{-1}$ for $0.8 \mathrm{~s}$, which was then used to produce the maximum fluorescence yield by temporarily inhibiting photosystem II (PSII) photochemistry. Measurements of minimum fluorescence yield were carried out in the presence of far-red light $\left(5 \mu \mathrm{mol} \mathrm{m}{ }^{-2} \mathrm{~s}^{-1}\right)$ in order to fully oxidize the PSII acceptor side. We determined $A_{\mathrm{sat}}, g_{\mathrm{s}}$, intercellular $\mathrm{CO}_{2}$ concentration $\left(C_{\mathrm{i}}\right)$ and transpiration rate $\left(T_{\mathrm{r}}\right)$. Foliar water use efficiency (WUE) was expressed as the ratio of $A_{\mathrm{sat}}$ and $T_{\mathrm{r}}$. The fluorescence parameters including actual photochemical efficiency of PSII in the saturated light $\left(\mathrm{Fv}^{\prime} / \mathrm{Fm}^{\prime}\right)$, quenching of photochemical efficiency of PSII ( $q \mathrm{P})$ and effective quantum yield of PSII photochemistry $\left(\Phi_{\mathrm{PSII}}\right)$ were calculated as follows: $\mathrm{Fv}^{\prime} / \mathrm{Fm}^{\prime}=\left(\mathrm{Fm}^{\prime}-\mathrm{Fo}^{\prime}\right) / \mathrm{Fm}^{\prime}, q \mathrm{P}=\left(\mathrm{Fm}^{\prime}-\mathrm{F}\right) /\left(\mathrm{Fm}^{\prime}-\mathrm{Fo}^{\prime}\right)$ (Bradbury and Baker, 1984; Quick and Horton, 1984) and $\Phi_{\mathrm{PSII}}=(\mathrm{Fm}-\mathrm{Fs}) / \mathrm{Fm}^{\prime}(\mathrm{Genty}$ et al., 1989).

\subsubsection{Total chlorophyll content measurement}

Total chlorophyll content was non-destructively measured on leaves used for gas exchange and fluorescence analysis with a SPAD chlorophyll meter (SPAD-520, Minoltam, Japan). Three readings per leaf were averaged to give value.

\subsection{Statistical analysis}

As gas exchange parameters were not significantly different between chambers within $\mathrm{O}_{3}$ treatment, the values for each plant were used as an independent experimental unit throughout the statistics. The original data were checked for normality and homogeneity of variance, then subjected to analysis of variance with general linear model to test the effects of $\mathrm{O}_{3}$, leaf age, measurement date and their interaction using SPSS 16.0 software package for Windows. The Tukey's HSD test was used to compare response difference among leaf age, measurement date and the interaction between $\mathrm{O}_{3}$, leaf age and measurement date. Furthermore, the means of AA and $\mathrm{E}^{-} \mathrm{O}_{3}$ at any leaf layer was compared using Student's $t$-tests. $P \leq 0.05$ was regarded as significant. Data shown in Figures were means $\pm \operatorname{SE}(n=5$ or 6).

\section{Results}

During $\mathrm{O}_{3}$ fumigation in 2010, the mean of the daily $8 \mathrm{~h} \mathrm{O}$ concentration (M8) in AA averaged $31 \mathrm{ppb}$ with a maximum of $78 \mathrm{ppb}$, while $\mathrm{M} 8$ in $\mathrm{E}_{-} \mathrm{O}_{3}$ averaged $67 \mathrm{ppb}$ with a maximum of $131 \mathrm{ppb}$ (Table 1 ). In addition, the accumulated $\mathrm{O}_{3}$ exposure over a threshold of $40 \mathrm{ppb}$ (AOT40) in AA and $\mathrm{E}-\mathrm{O}_{3}$ by the end of each fumigation season was 5.8 and $34.5 \mathrm{ppm} \mathrm{h}$ in 2009 and 3.5 and $43.5 \mathrm{ppm}$ h in 2010 , respectively. 
Table 1

8-h mean $\mathrm{O}_{3}$ concentration (M8) and AOT40 for ambient (AA) and elevated $\mathrm{O}_{3}\left(\mathrm{E}-\mathrm{O}_{3}\right)$ treatments (8:00-16:00) during the 2009 and 2010 growing seasons.

\begin{tabular}{cccccc}
\hline & \multicolumn{2}{l}{2009 (25th May-10th Sep.) } & & \multicolumn{2}{l}{2010 (2nd May-13th Oct.) } \\
\cline { 2 - 3 } & $\mathrm{AA}$ & $\mathrm{E}-\mathrm{O}_{3}$ & & $\mathrm{AA}$ & $\mathrm{E}-\mathrm{O}_{3}$ \\
\hline $\begin{array}{c}\text { Average of } \\
\text { M8 }(\mathrm{ppb})\end{array}$ & 32.0 & 60.3 & & 32.1 & 66.9 \\
$\begin{array}{c}\text { Maximum } \\
\text { M8 }(\mathrm{ppb})\end{array}$ & 97.6 & 159.7 & & 78.0 & 131.1 \\
$\begin{array}{c}\text { Minimum } \\
\text { M8 }(\mathrm{ppb})\end{array}$ & 14.9 & 74.9 & & 9.2 & 69.1 \\
AOT40 (ppm h) & 5.8 & 34.5 & & 3.5 & 43.5
\end{tabular}

Across the three measurement campaigns, significant differences in total chlorophyll contents were detected in response to $\mathrm{O}_{3}$, leaf age and measurement date, but not in interactions between $\mathrm{O}_{3}$ and leaf age or $\mathrm{O}_{3}$ and date (Fig. 1, Table 2). However, the impacts of $\mathrm{E}_{-} \mathrm{O}_{3}$ on leaves with three ages differed at the different measurement dates, as indicated by the significant interaction between $\mathrm{O}_{3} \times$ age $\times$ date $(P<0.001$, Table 2$)$. As can been seen from Fig. 1, E- $\mathrm{O}_{3}$ induced a larger reduction in chlorophyll content in the upper leaves (Layer 14 to Layer 20, NFL and YL) than in the lower canopy of plants (ML) at the 3rd measurement, whereas all leaf ages showed a similar response to $\mathrm{E}^{-} \mathrm{O}_{3}$ at both the 1 st and 2nd measurements.

Across all measurements, $A_{\text {sat }}$ and $g_{s}$ were significantly affected by $\mathrm{E}-\mathrm{O}_{3}$, leaf age and their interactions, but not $\mathrm{O}_{3} \times$ age $\times$ date (Table 2), suggesting that the reduced $A_{\text {sat }}$ and $g_{\mathrm{s}}$ with E-O $\mathrm{O}_{3}$ differed between leaf ages throughout the measurements. Fig. 2 shows that E- $\mathrm{O}_{3}$ significantly decreased $A_{\mathrm{sat}}$ only in NFL at the 2nd measurement, NFL and YL at the 3rd measurement, and $g_{\mathrm{s}}$ only in YL and NFL leaves at the 2 nd measurement. $A_{\text {sat }}$ and $g_{\mathrm{s}}$ in ML showed little response to $\mathrm{E}_{-} \mathrm{O}_{3}$. Moreover, the leaves in lower part of canopy (ML) had a much lower $A_{\mathrm{sat}}$ and $g_{\mathrm{s}}$ than the upper leaves (NFL and YL) (Fig. 2, Table 2). In contrast, $\mathrm{E}-\mathrm{O}_{3}$ did not significantly affect $C_{\mathrm{i}}$ or WUE at any leaf age or leaf layer throughout the course of the measurements (Table 2, Fig. 2).

For chlorophyll $a$ fluorescence, $\mathrm{Fv}^{\prime} / \mathrm{Fm}^{\prime}$ and $q \mathrm{P}$ were significantly reduced by $\mathrm{E}_{-} \mathrm{O}_{3}$ across all measurements, but were not affected by the interaction of $\mathrm{O}_{3} \times$ age or $\mathrm{O}_{3} \times$ age $\times$ date (Fig. 3 , Table 2). However, $\mathrm{E}_{-} \mathrm{O}_{3}$ significantly reduced the $\Phi_{\mathrm{PSII}}$ in both NFL and YL but not ML, as shown by the significant interaction of $\mathrm{O}_{3}$ and age (Fig. 3, Table 2). For all three parameters, ML at any leaf layer did not show a significant response to $\mathrm{E}-\mathrm{O}_{3}$ at any measurement.
Table 2

Main and interactive effects of elevated $\mathrm{O}_{3}$, leaf age and measurement date on leaf photosynthesis parameters of Cyclobalanopsis glauca seedlings in the 2010 growing season.

\begin{tabular}{|c|c|c|c|c|c|c|}
\hline \multirow[t]{2}{*}{ Parameters } & \multicolumn{3}{|c|}{ Main effects } & \multicolumn{3}{|c|}{ Interactive effects } \\
\hline & $\mathrm{O}_{3}$ & Age & Date & $\mathrm{O}_{3} \times$ date & $\mathrm{O}_{3} \times$ age & $\begin{array}{l}\mathrm{O}_{3} \times \text { age } \times \\
\text { date }\end{array}$ \\
\hline$A_{\text {sat }}$ & $<0.001$ & $<0.001$ & 0.177 & 0.84 & 0.04 & 0.11 \\
\hline$g_{s}$ & $<0.001$ & $<0.001$ & $<0.001$ & 0.23 & 0.01 & 0.88 \\
\hline$C_{\mathrm{i}}$ & 0.65 & 0.07 & $<0.001$ & 0.77 & 0.64 & 0.59 \\
\hline WUE & 0.94 & 0.008 & $<0.001$ & 0.71 & 0.61 & 0.55 \\
\hline $\mathrm{Fv}^{\prime} / \mathrm{Fm}^{\prime}$ & $<0.001$ & $<0.001$ & $<0.001$ & 0.22 & 0.21 & 0.18 \\
\hline$\Phi_{\text {PSII }}$ & $<0.001$ & $<0.001$ & $<0.001$ & 0.69 & 0.003 & 0.13 \\
\hline$q \mathrm{P}$ & 0.052 & $<0.001$ & 0.003 & 0.61 & 0.35 & 0.22 \\
\hline Chl & $<0.001$ & $<0.001$ & $<0.001$ & 0.44 & 0.58 & $<0.001$ \\
\hline
\end{tabular}

\section{Discussion}

Elevated $\mathrm{O}_{3}$ induced significant decreases in total chlorophyll content, net photosynthesis rate and $g_{s}$ across all leaf ages/layers of C. glauca (Table 2), in accordance with responses of other tree species, e.g. Cinnamonum campora (Feng et al., 2011), Viburnum lantana (Calatayud et al., 2010), poplar (Bohler et al., 2010), aspen (Noormets et al., 2001) and beech (Bortier et al., 2008). Also, Fv'/Fm' and $\Phi_{\mathrm{PSII}}$ but not $q \mathrm{P}$ were significantly reduced by $\mathrm{E}-\mathrm{O}_{3}$, suggesting that $\mathrm{E}-\mathrm{O}_{3}$ increased light energy dissipation of the antenna pigment, thus leading to a reduction in the efficiency of excitation energy captured by the open PSII reaction center, but no change on the proportion of open PSII reaction center. All these indicated that both dark and light reactions of photosynthesis of $C$. glauca were negatively affected by elevated $\mathrm{O}_{3}$ after two years exposure (Figs. 2 and 3). On the basis of Farquhar and Sharkey (1982), the response of gas exchange parameters (reduced $A_{\mathrm{sat}}$ and $g_{\mathrm{s}}$, and no change of $C_{\mathrm{i}}$ ) to $\mathrm{E}-\mathrm{O}_{3}$ indicated that the decrease in net photosynthetic rate might not be fully explained by stomatal closure but by the decrease in the assimilation capacity. No difference in WUE between $\mathrm{O}_{3}$ treatments was found for any measured leaves during the growing season (Fig. 2), suggesting that $\mathrm{O}_{3}$ exposure may reduce photosynthetic decline in parallel with stomatal closure.

From Table 2, the lack of a significant interaction between $\mathrm{O}_{3}$ and date indicated that the effects of $\mathrm{E}^{-} \mathrm{O}_{3}$ on all tested parameters were fairly constant over time, i.e. the relative negative impacts of $\mathrm{E}-\mathrm{O}_{3}$ on photosynthesis did not change with leaves and canopy development. However, a significant interaction between $\mathrm{O}_{3}$ and leaf age was found on $A_{\mathrm{sat}}, g_{\mathrm{s}}$ and $\Phi_{\mathrm{PSII}}$, suggesting that the negative effect of $\mathrm{E}-\mathrm{O}_{3}$ was strongly dependent on leaf age, as demonstrated by larger effects of $\mathrm{E}^{-\mathrm{O}_{3}}$ on NFL and YL than ML (Figs. 2 and 3). $A_{\text {sat }}$

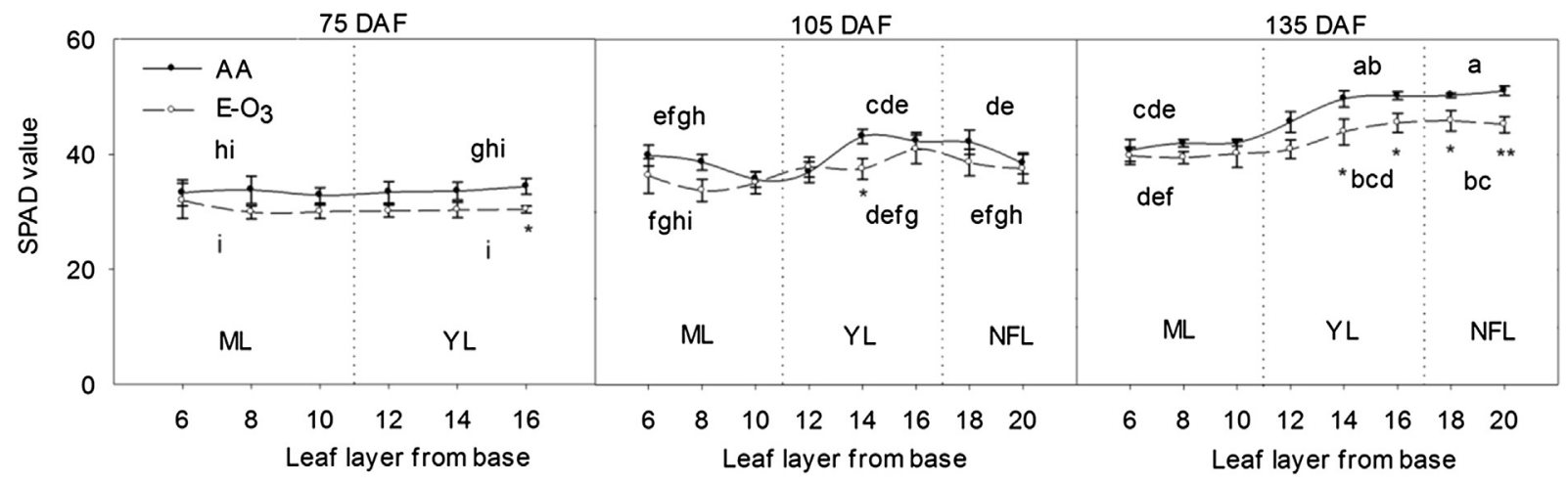

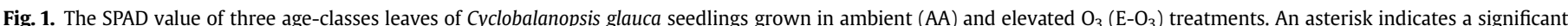

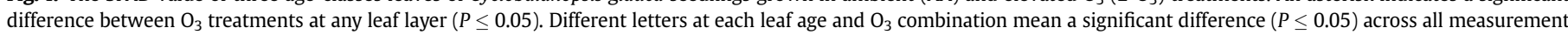

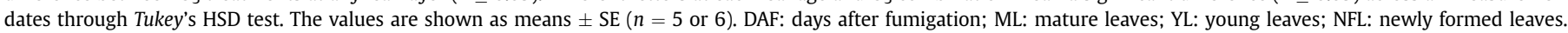




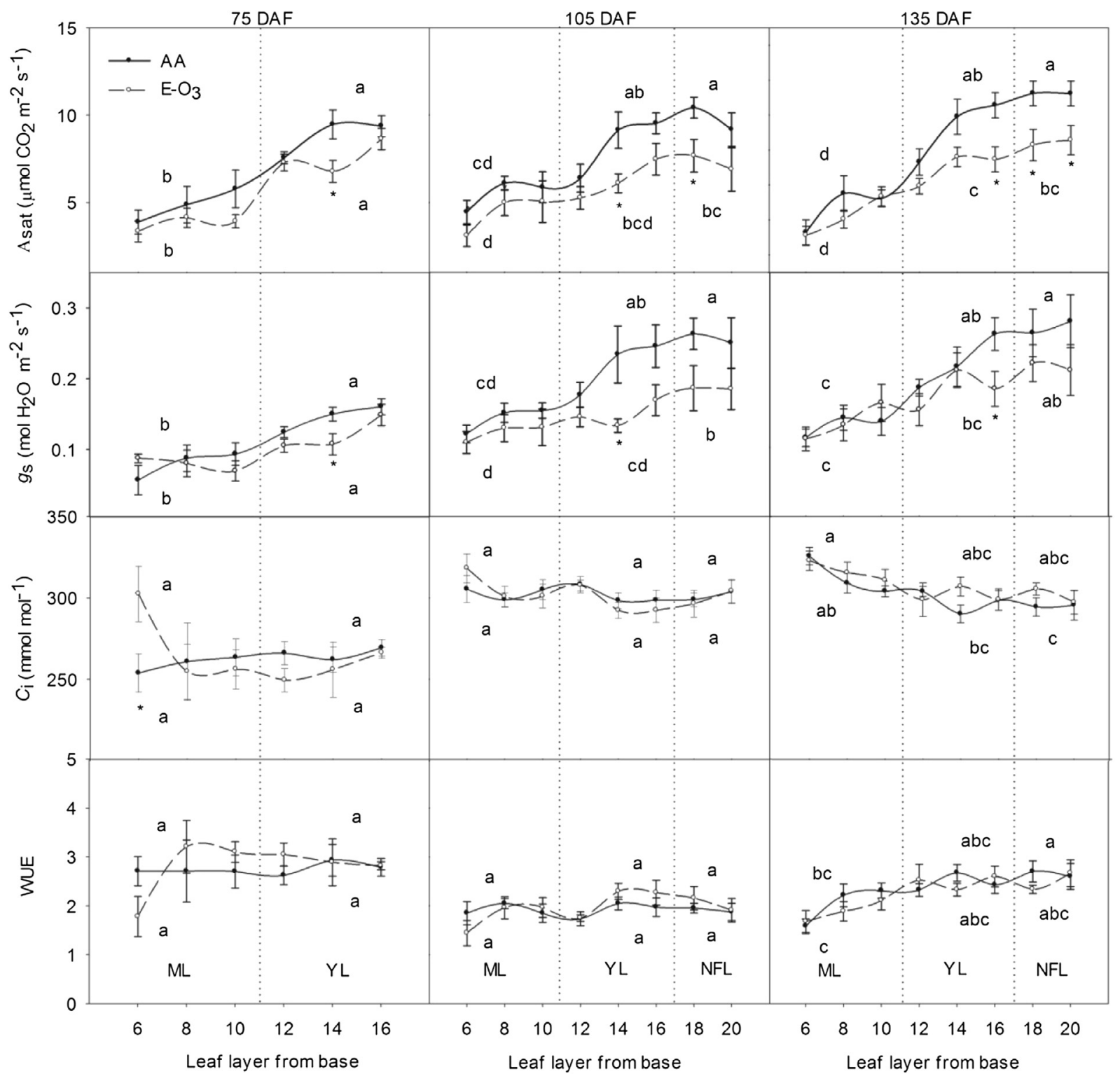

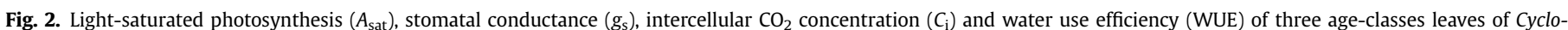

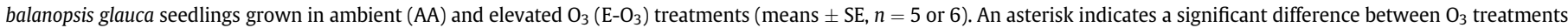

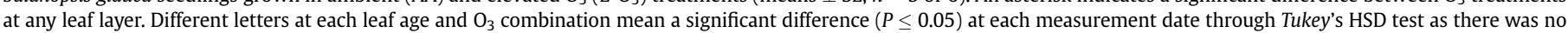

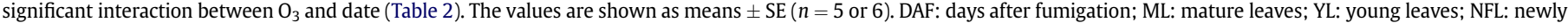
formed leaves.

and $\Phi_{\text {PSII }}$ was significantly reduced by $\mathrm{E}_{-} \mathrm{O}_{3}$ in both NFL and $\mathrm{YL}$, and stomatal closure by $\mathrm{E}_{-} \mathrm{O}_{3}$ was only detected in $\mathrm{YL}$ leaves on the middle canopy. However, the results on the deciduous species indicated that $\mathrm{E}-\mathrm{O}_{3}$ caused larger effects on old leaves of the lower canopy than young leaves of the upper canopy e.g. poplar, silver birch (Bortier et al., 2000; Mäenpää et al., 2011; Reich, 1983), and the developing leaves of silver birch (Betula pendula Roth.) were more tolerant to $\mathrm{O}_{3}$ than expanded leaves (Pääkkönen et al., 1996). Therefore, the response of evergreen tree species C. glauca to $\mathrm{E}-\mathrm{O}_{3}$ at different leaf ages or leaf layers was a bit different from that of tested deciduous species, possibly attributable to the difference in leaf development traits between evergreen and deciduous species.

Although we did not measure $\mathrm{O}_{3}$ concentration along the vertical profile in this experiment, the OTC we used was the same design as that previously used in a rice experiment (Zheng et al., 2007). The $\mathrm{O}_{3}$ concentration at three heights of 50,85 and $130 \mathrm{~cm}$ from the ground

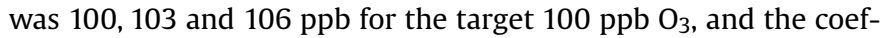
ficient of variation was 1.01, 1.07 and 1.07, respectively, indicating that ozone concentration of both vertical and horizontal distribution was equable and stable in our OTCs (Zheng et al., 2007). This indicated that the upper and lower canopies were exposed to similar $\mathrm{O}_{3}$ concentration during the fumigation.

A significant linear relationship between the response of $A_{\text {sat }}$ to $\mathrm{E}-\mathrm{O}_{3}$ and $g_{\mathrm{s}}$ of ambient plants $\left(r^{2}=0.18, N=22, P=0.048\right)$ suggested that $g_{s}$ partially contributed to the different response to $\mathrm{O}_{3}$ among leaf layers or leaves of different ages. Therefore, the observed larger photosynthetic response to $\mathrm{E}_{-} \mathrm{O}_{3}$ in $\mathrm{YL}$ can be explained by greater $g_{s}$ in the upper canopy relative to ML. Apparently, stomatal $\mathrm{O}_{3}$ uptake was much greater in the upper canopy (i.e. NFL and YL) than lower canopy (i.e. ML). However, it does not imply that cumulative $\mathrm{O}_{3}$ uptake at upper canopy was more than that at lower canopy because ML had been exposed to $\mathrm{O}_{3}$ 


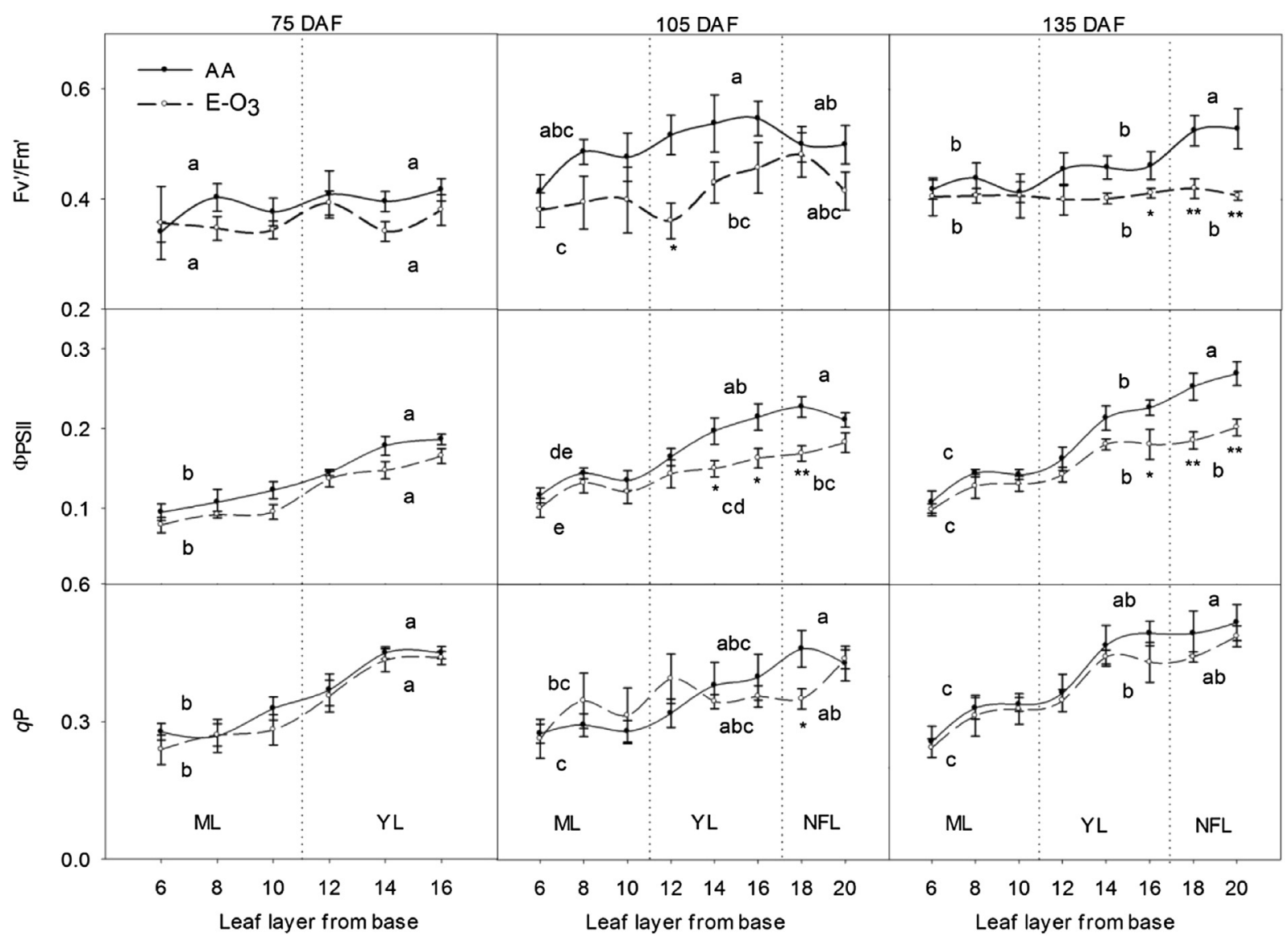

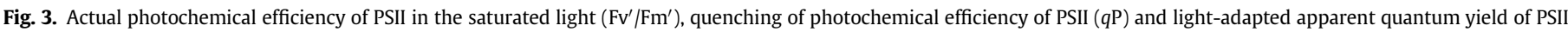

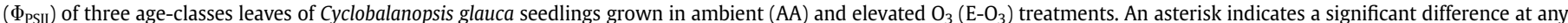

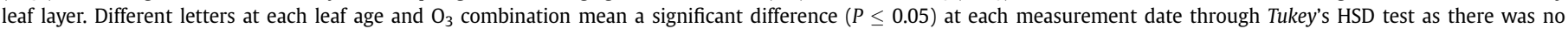

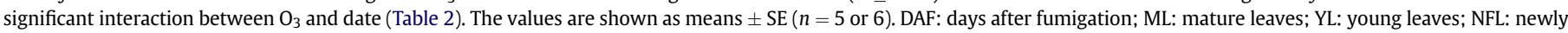
formed leaves.

exposure for one year longer than NFL and YL. Moreover, termination of $\mathrm{O}_{3}$ exposure may allow previous-year leaves to recover from $\mathrm{O}_{3}$ damage and confer tolerance to subsequent $\mathrm{O}_{3}$ exposure. Therefore, lower $A_{\mathrm{sat}}$ and $g_{\mathrm{s}}$ at ML may also be a result of adaptation or acclimation of plants to high $\left[\mathrm{O}_{3}\right]$. The variation of $g_{\mathrm{s}}$ from the apex along the vertical plant axis has been suggested to correspond with the degree of shading and age of the leaves (Herbinger et al., 2005; Kitao et al., 2006; Paoletti and Grulke, 2005).

Possibly, other factors such as foliar detoxification capacity also play an important role in different responses to $\mathrm{E}-\mathrm{O}_{3}$ between leaves of different position or age. Fares et al. (2010) found that a changing defense against $\mathrm{O}_{3}$ along the plant axis in Populus nigra was attributed to a vertical profile of foliar phenolic and volatile compounds. In accordance with their study, concentrations of antioxidants and secondary products were observed higher in sun leaves or upper canopy foliage of Fagus sylvatica L., including significantly increased glutathione concentrations under double $\mathrm{O}_{3}$ concentration across both age classes and canopy levels (Herbinger et al., 2005).

\section{Conclusions}

From the present study, elevated $\mathrm{O}_{3}$ decreased the photosynthetic parameters of current-year leaves but not previous-year leaves in evergreen $C$. glauca, suggesting that leaf age should be considered when assessing carbon assimilation loss of evergreen species exposed to long-term $\mathrm{O}_{3}$. Stomatal conductance of plants at different leaf layers partially contributed to the different response to $\mathrm{E}-\mathrm{O}_{3}$ between leaf ages. However, information on other physiological and biochemical processes closely related to photosynthesis is needed to determine which factors are crucial to the differential responses to $\mathrm{E}_{-} \mathrm{O}_{3}$ among leaves of different ages or layers.

\section{Acknowledgments}

This research was supported by the National Natural Science Foundation of China (No. 30700086) and Hundred Talent Program, Chinese Academy of Sciences. We gratefully acknowledge Dr. Xihua Wang, Ms. Fangfang Yao and Dr. Yuan Tian for supporting experimental site and ozone monitoring, respectively. We also express our appreciation to Dr. Felicity Hays for English improvement throughout the manuscript.

\section{References}

Bagard, M., Le Thiec, D., Delacote, E., Hasenfratz-Sauder, M.P., Banvoy, J., Gérard, J. Dizengremel, P., Jolivet, Y., 2008. Ozone-induced changes in photosynthesis and photorespiration of hybrid poplar in relation to the developmental stage of the leaves. Physiologia Plantarum 134, 559-574.

Bohler, S., Sergeant, K., Lefèvre, I., Jolivet, Y., Hoffmann, L., Renaut, J., Dizengremel, P., Hausman, J.F., 2010. Differential impact of chronic ozone exposure on expanding and fully expanded poplar leaves. Tree Physiology 30, 1415-1432.

Bortier, K., Ceulemans, R., de Temmerman, L., 2008. Effects of ozone exposure on growth and photosynthesis of beech seedlings (Fagus sylvatica). New Phytologist 146, 271-280. 
Bortier, K., De Temmerman, L., Ceulemans, R., 2000. Effects of ozone exposure in open-top chambers on poplar (Populus nigra) and beech (Fagus sylvatica): a comparison. Environmental Pollution 109, 509-516.

Bradbury, M., Baker, N.R., 1984. A quantitative determination of photochemical and non-photochemical quenching during the slow phase of the chlorophyll fluorescence induction curve of bean leaves. Biochimica et Biophysica Acta (BBA) Bioenergetics 765, 275-281.

Calatayud, V., Marco, F., Cerveró, J., Sánchez-Peña, G., José Sanz, M., 2010. Contrasting ozone sensitivity in related evergreen and deciduous shrubs. Environmental Pollution 158, 3580-3587.

Coleman, M.D., Isebrands, J.G., Dickson, R.E., Karnosky, D.F., 1995. Photosynthetic productivity of aspen clones varying in sensitivity to tropospheric ozone. Tree Physiology 15, 585-592.

Fares, S., Oksanen, E., Lännenpää, M., Julkunen-Tiitto, R., Loreto, F., 2010. Volatile emissions and phenolic compound concentrations along a vertical profile of Populus nigra leaves exposed to realistic ozone concentrations. Photosynthesis Research 104, 61-74.

Farquhar, G.D., Sharkey, T.D., 1982. Stomatal conductance and photosynthesis Annual Review of Plant Physiology 33, 317-345.

Feng, Z.Z., Kobayashi, K., 2009. Assessing the impacts of current and future concentrations of surface ozone on crop yield with meta-analysis. Atmospheric Environment 43, 1510-1519.

Feng, Z.Z., Niu, J.F., Zhang, W.W., Wang, X.K., Yao, F.F., Tian, Y., 2011. Effects of ozone exposure on sub-tropical evergreen Cinnamomum camphora seedlings grown in different nitrogen loads. Trees-Structure and Function 25, 1-9.

Genty, B., Briantais, J.M., Baker, N.R., 1989. The relationship between the quantum yield of photosynthetic electron transport and quenching of chlorophyll fluorescence. Biochimica et Biophysica Acta (BBA)-General Subjects 990, 87-92.

Greitner, C.S., Pell, E.J., Winner, W.E., 1994. Analysis of aspen foliage exposed to multiple stresses: ozone, nitrogen deficiency and drought. New Phytologist 127 $579-589$.

Herbinger, K., Then, Ch., Löw, M., Haberer, K., Alexous, M., Koch, N., Remele, K., Heerdt, C., Grill, D., Rennenberg, H., Häberle, K.-H., Matyssek, R., Tausz, M. Wieser, G., 2005. Tree age dependence and within-canopy variation of leaf gas exchange and antioxidative defence in Fagus sylvatica under experimental freeair ozone exposure. Environmental Pollution 137, 476-482.

Kitao, M., Lei, T.T. Koike, T., Tobita, H., Maruyama, Y., 2006. Tradeoff between shade adaptation and mitigation of photoinhibition in leaves of Quercus mongolica and Acer mono acclimated to deep shade. Tree Physiology 26, 441-448.

Mäenpää, M., Riikonen, J., Kontunen-Soppela, S., Rousi, M., Oksanen, E., 2011. Vertical profiles reveal impact of ozone and temperature on carbon assimilation of Betula pendula and Populus tremula. Tree Physiology 31, 808-818.

Noormets, A., Sôber, A., Pell, E.J., Dickson, R.E., Podila, G.K., Sôber, J., Isebrands, J.G. Karnosky, D.F., 2001. Stomatal and non-stomatal limitation to photosynthesis in two trembling aspen (Populus tremuloides Michx.) clones exposed to elevated $\mathrm{CO}_{2}$ and/or $\mathrm{O}_{3}$. Plant, Cell and Environment 24, 327-336.
Novak, K., Schaub, M., Fuhrer, J., Skelly, J.M., Hug, C., Landolt, W., Bleuler, P., Kräuchi, N., 2005. Seasonal trends in reduced leaf gas exchange and ozoneinduced foliar injury in three ozone sensitive woody plant species. Environmental Pollution 136, 33-45.

Pääkkönen, E., Metsärinne, S., Holopainen, T., Kärenlampi, L., 1996. The ozone sensitivity of birch (Betula pendula) in relation to the developmental stage of leaves. New Phytologist 132, 145-154.

Paoletti, E., Contran, N., Bernasconi, P., Günthardt-Goerg, M.S., Vollenweider, P., 2009. Structural and physiological responses to ozone in Manna ash (Fraxinus ornus L.) leaves of seedlings and mature trees under controlled and ambient conditions. Science of The Total Environment 407, 1631-1643.

Paoletti, E., Grulke, N.E., 2005. Does living in elevated $\mathrm{CO}_{2}$ ameliorate tree response to ozone? A review on stomatal responses. Environmental Pollution 137, 483493.

Quick, W.P., Horton, P., 1984. Studies on the induction of chlorophyll fluorescence in barley protoplasts. II. Resolution of fluorescence quenching by redox state and the transthylakoid pH gradient. Proceedings of The Royal Society of London. Series B. Biological Sciences 220, 371-382.

Reich, P.B., 1983. Effects of low concentrations of $\mathrm{O}_{3}$ on net photosynthesis, dark respiration, and chlorophyll contents in aging hybrid poplar leaves. Plant Physiology 73, 291-296.

Samuelson, L.J., Edwards, G.S., 1993. A comparison of sensitivity to ozone in seedlings and trees of Quercus rubra L. New Phytologist 125, 373-379.

Schaub, M., Skelly, J.M., Zhang, J.W., Ferdinand, J.A., Savage, J.E., Stevenson, R.E., Davis, D.D., Steiner, K.C., 2005. Physiological and foliar symptom response in the crowns of Prunus serotina, Fraxinus Americana and Acer rubrum canopy trees to ambient ozone under forest conditions. Environmental Pollution 133, 553-567.

The Royal Society, 2008. Ground-level Ozone in the 21st Century: Future Trends, Impacts and Policy Implications. Science Policy Report 15/08. The Royal Society, London.

Watanabe, M., Yamaguchi, M., Matsumura, H., Kohno, Y., Izuta, T., 2008. Effects of ozone on the growth and photosynthesis of Castanopsis sieboldii seedlings grown under different nitrogen loads. Journal of Agricultural Meteorology 64 143-155.

Wittig, V.E., Ainsworth, E.A., Naidu, S.L., Karnosky, D.F., Long, S.P., 2009. Quantifying the impact of current and future tropospheric ozone on tree biomass, growth, physiology and biochemistry: a quantitative meta-analysis. Global Change Biology 15, 396-424.

Zhang, J.M., Schaub, M., Ferdinand, J.A., Skelly, J.M., Steiner, K.C., Savage, J.E., 2010. Leaf age affects the responses of foliar injury and gas exchange to tropospheric ozone in Prunus serotina seedlings. Environmental Pollution 158, 2627-2634.

Zheng, Q.W., Wang, X.K., Feng, Z.Z., Song, W.Z., Feng, Z.W., OU Yang, Z.Y., 2007. Effects of elevated ozone on biomass and yield of rice planted in open-top chamber with revolving ozone distribution. Environmental Science 28, 170175 (in Chinese) 